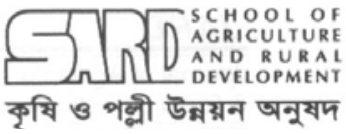

\title{
A Study on Comparative Performances of Hybrid and Convential Rice Varieties in Aman Season
}

\author{
M.A. AWAL ${ }^{1}$, A.K.M.A. HABIB ${ }^{2}$ AND M.A. HosSAIN ${ }^{3 *}$ \\ ${ }^{1 \& 2}$ Regional Agricultural Research Station, Bangladesh Agricultural Research Institute, Rahmatpur, Barisal \\ ${ }^{3}$ T\&C, Bangladesh Agricultural Research Institute, Joydebpur, Gazipur, Bangladesh
}

\begin{abstract}
An experiment was done at farmer's field in Sherpur district to evaluate the comparative performance of two hybrid rice varieties, Sonarbangla-2 and Sonarbangla-3 with three conventional modern commercial varieties BRRIdhan32, BRRIdhan33 and BR11 in Transplanted aman season of 2003. It is revealed that the hybrids and conventional rice varieties differed significantly among themselves with respect to different parameters under study. The highest grain yield (6.20t/ha) was recorded from the hybrid Sonarbangla-3 followed BRRIdhan-32 (5.70 t/ha) and the lowest in BRRIdhan-33 (4.17t/ha) and these differences were statistically significant. However, BRRIdhan-32 obtained significantly higher yield compared to the hybrid Sonarbangla-2. Further, it produced the maximum amount of straw (8.6 t/ha), which varied significantly with all others. Minimum days to $1^{\text {st }}$ flowering (92) and maturity (108) were noticed in Sonarbangla-2 followed by Sonarbangla-3 (95 and 115), respectively. Both the hybrid had heavier grain weight (28.33-31.00g) than those of the conventional varieties (22-25g). It is noted that the hybrids maintained distinct statistical edge over the conventional varieties with regard to most of the parameters. Thus, the hybrid Sonarbangla-3 was found superior to conventional varieties for transplanting in the aman season in Bangladesh.
\end{abstract}

Key words: Sonarbangla-2, Sonarbangla-3, conventional varieties, cropping pattern.

\section{INTRODUCTION}

Rice plays an important role in the economy of Bangladesh. It is by far the most important food crop in Asia. Extension of rice area through increased rice production under irrigated condition is a herculean task. The conventional varieties of rice in Bangladesh are comparatively lower-yield and it seems impossible to change this yield with reachable resources under the prevailing situation. At this stage, hybrid varieties of rice may be a breakthrough, which could overcome perpetual yield stagnancy. To feed ever increasing hungry millions of Bangladesh, there is no option but go for hybrid rice. Therefore, development and introduction of hybrid varieties should get topmost priority especially in irrigated MV rice. The national average yield of rice in Bangladesh is low (2.77t/ha), while yields of the other rice growing countries of Asia such as, China, Taiwan, Indonesia, and Japan are 5.72, 4.60, 4.38, and $5.97 \mathrm{t} / \mathrm{ha}$, respectively (Quayum et al.1996). Bangladesh has been facing acute shortage of rice for a long time to cope with rapid rise of population. Therefore, it has become indispensable to produce more rice to achieve the goal of self-sufficiency in food. Accordingly, production per unit of land area as well as maximum cropping intensity are crucial factors. However, yields of existing modern rice varieties have become stale-mate. Hybrid rice was

"Corresponding author: Scientific Officer (Agril. Econ.), RARS, Rahmatpur, Barisal, Phone: 0431/52730/56520/53050

(C) 2006 School of Agriculture and Rural Development, Bangladesh Open University, All rights reserved. 


\section{A. Awal et al.}

successfully developed in China where about 50\% rice area is now under it (Yuan, 1994). Hybrid rice in China produced a yield advantage of 1.0-1.5 t/ha (20-30\%) over the conventionally bred varieties (Virmani, 1994). India and Vietnam are also successful in developing semi-dwarf modern hybrid varieties of rice as a viable alternative. Chandra et al. (1992) conducted a study with hybrids derived from the CMS lines IR62829A and IR 58025A. They noticed that hybrids of the latter surpassed the yields of the IR62829A hybrids and the control varieties such as,Joya, IR36 as well as hybrids of IR58025AxIR9761-19-IR and IR58025 x IR35366-62-2-2-3R. A good hybrid rice has the potential of yielding $14-28 \%$ more than the best inbred or pure line variety grown under similar environmental conditions (Siddiq, 1993). Bangladesh has recently introduced some hybrid rice varieties from China and India. Therefore, the present experiment was undertaken to evaluate performances of hybrid rice in comparison with the recently BRRI released rice varieties in Aman season at the farmer's field of Sherpur district in 2003.

\section{Justification of the study}

Rice is a major source of livelihood in terms of providing food, income and employment for majority people in Bangladesh. Rice production in Bangladesh remained almost stagnant in the 1950s at around 11 to 12 million tonnes. But the population growth rate accelerated from less than 1 per cent per year during the first half of the century to 2.5 per cent during $1950 \mathrm{~s}$, causing concern for Bangladesh's ability to feed the added people. The early 1970s was a period of stagnation because of disputation in production and destruction of infrastructure caused by the War of Independence in 1971, and successive crop failures caused by draught and floods. After the liberation in the mid1980s, reduced tariffs on the import of agricultural machinery, removal of ban on private imports, and deregulation in the prices of agricultural inputs put further impetus to the expansion of irrigation, particularly the extraction of ground water through shallow tubewell. (Hossain, 1996pp.285-40).

Due to exploitation of a new technology, area under modern varieties spread rapidly and reached about two-third of the cropped area by 2003. The expansion of cropped area (through increase in rice cropping intensity and replacement of land from non-rice crops), which was an important source of production growth till the mid 1980s, has dried up. The increase in domestic production is now entirely dependent on growth in rice yield. Indeed, Bangladesh must aim a higher rate of growth in yield than the required increase in rice supplies to meet the demand, in order to release land for other crops demand of which has been growing faster than that of rice. Rice breeders have, therefore, been trying varieties (HYV) to increase the yield while sustaining the natural resources base. One innovation has been the development of hybrid rice varieties for the tropics, which is expected to shift the yield potential of the rice plant by 15-20 per cent or more. The technology has attracted the attention of research leaders and policy-makers in Bangladesh who see it as an opportunity to overcome the yield ceilings reached by many enterprising farmers in the irrigated ecosystem. Here lies the necessity for conducting the study.

\section{MATERIALS AND METHODS}

An experiment was carried out with two hybrid rice varieties (Sonarbangla-2 and Sonarbangla-3) and three conventional varieties as checks (BR-11, BRRIdhan-32 and 33 ) at farmer's field in Sherpur district during the Transplanted aman season of 2003. The land type of the experimental field was medium high, sandy loam in texture and with $\mathrm{P}^{\mathrm{H}} 6.5$. It belongs to the old Brahmaputra alluvial soil tract (Brammer et.al. 1988). Experimental site was affected by high temperature (maximum $32.30^{\circ} \mathrm{C}$ ), heavy rainfall (maximum $362.1 \mathrm{~mm}$ ) and high humidity (maximum87.19\%) during the study period. The experiment was laid out in a Randomized Complete Block Design (RCBD) with three replications. The plot size was $5 \mathrm{~m} \times 4 \mathrm{~m}$. The fertilizers were applied @ 245, 110 and $95 \mathrm{~kg} / \mathrm{ha}$ Urea, TSP and MP, respectively. Full doses of TSP and MP were applied at the time of final land preparation. Urea was applied in three equal splits. One third was applied as basal and the remaining was top dressed at 30 and 60 days after transplanting. Forty days old seedlings were transplanted with a spacing of $25 \mathrm{~cm} \times 15 \mathrm{~cm}$. The plantation was done on11 August 2003. Intercultural operations such as, weeding, irrigation, pesticide applications etc were followed to ensure normal healthy growth of the plants. The data on first flowering, days to harvest, 
yield and yield contributing characters were recorded, analyzed statistically and the means were compared by Duncan's Multiple Range Test (DMRT) (Gomez and Gomez, 1984).

\section{RESULTS AND DISCUSSION}

Data on yield and yield contributing characters are presented in Table 1. It is revealed that both the hybrid and the conventional varieties exerted significant influence on the parameters under study.

Table 1. Comparative performances of the exotic hybrid rice varieties with the modern conventional varieties at the farmer's field of Sherpur district in 2003.

\begin{tabular}{|c|c|c|c|c|c|c|c|c|c|c|c|c|c|}
\hline Variety & $\begin{array}{c}\text { Plant } \\
\text { height } \\
\text { (cm ) }\end{array}$ & $\begin{array}{c}\text { Effective } \\
\text { tiller/hill } \\
\text { (No.) }\end{array}$ & $\begin{array}{c}\text { Non } \\
\text { effective } \\
\text { tiller/hill } \\
\text { (no.) }\end{array}$ & $\begin{array}{l}\text { Panicle } \\
\text { length } \\
\text { (cm) }\end{array}$ & $\begin{array}{c}\text { Panicle } \\
\text { /hill } \\
\text { (no.) }\end{array}$ & $\begin{array}{c}\text { Filled } \\
\text { grain } \\
\text { /panicle } \\
\text { (no.) } \\
\end{array}$ & $\begin{array}{c}\text { Unfilled } \\
\text { grain/ } \\
\text { panicle } \\
\text { (no.) }\end{array}$ & $\begin{array}{c}100 \\
\text { grain } \\
\text { weight } \\
(\mathrm{g}) \\
\end{array}$ & $\begin{array}{c}1 \text { st } \\
\text { Flowering } \\
\text { (days) }\end{array}$ & $\begin{array}{l}\text { Days to } \\
\text { maturity } \\
\text { (no.) }\end{array}$ & $\begin{array}{l}\text { Yield } \\
\text { (t/ha) }\end{array}$ & $\begin{array}{l}\text { Straw } \\
\text { yield } \\
\text { (t/ha) }\end{array}$ & $\begin{array}{l}\text { Harvest } \\
\text { Index } \\
(\%)\end{array}$ \\
\hline Sonarbangla-2 & $102.7 d$ & 7.67ab & $5.00 \mathrm{a}$ & 29.67ab & $9.33 a$ & $125.3 b$ & 24.0 & $31.00 \mathrm{a}$ & $92 \mathrm{c}$ & $108 \mathrm{c}$ & $5.15 c$ & $5.00 c$ & $50.0 a$ \\
\hline Sonarbangla-3 & $113.7 \mathrm{~b}$ & $9.00 \mathrm{a}$ & $2.67 \mathrm{~b}$ & $31.33 a$ & 8.67ab & $176.0 \mathrm{a}$ & 30.0 & $28.33 b$ & $95 c$ & $115 \mathrm{c}$ & $6.20 a$ & $6.5 b$ & $47.3 a$ \\
\hline BRRIdhan -32 & $119.0 \mathrm{a}$ & $8.00 a b$ & $1.00 \mathrm{c}$ & $28.33 b$ & $8.00 a b c$ & 149.0ab & 21.0 & $22.00 d$ & $114 \mathrm{~b}$ & $133 b$ & $5.70 b$ & $8.6 a$ & $39.6 b$ \\
\hline BRRIdhan33 & $103.7 d$ & $5.33 c$ & $2.00 \mathrm{~b}$ & $28.00 \mathrm{~b}$ & $6.67 \mathrm{c}$ & $130.0 \mathrm{~b}$ & 27.0 & $25.00 \mathrm{c}$ & $118 b$ & $139 b$ & $4.17 d$ & $4.2 \mathrm{c}$ & $49.6 a$ \\
\hline BR11 & $107.3 \mathrm{c}$ & $6.67 \mathrm{bc}$ & $2.00 \mathrm{~b}$ & $24.67 \mathrm{c}$ & $7.33 \mathrm{bc}$ & $123.3 \mathrm{~b}$ & 36.0 & $25.00 \mathrm{c}$ & $125 a$ & $150 a$ & $4.96 c$ & $5.0 \mathrm{c}$ & $49.8 a$ \\
\hline F-test & ** & $\star *$ & ** & ** & ** & ** & NS & * & ** & ** & ** & ** & ** \\
\hline CV(\%) & 5.16 & 4.30 & 3.60 & 3.40 & 4.66 & 7.96 & 6.5 & 0.49 & 2.32 & 2.25 & 3.18 & 5.84 & 3.40 \\
\hline
\end{tabular}

The common letter(s) do not differ at level of $p>0.01$ probability; NS= Not significant; *Exotic Hybrid rice varieties: Sonarbangla2 and 3; *Modern conventional rice varieties (Check):BR 11, BRRIdhan-32 and 33

Plant height: The tested varieties differed statistically with each other in respect of plant height. It was noticed that a conventional variety BRRIdhan-32 produced the tallest plants $(119 \mathrm{~cm})$ and the other treatments were statistically shorter than this. However, the hybrid Sonarbangla-3 had a notable height $(113.7 \mathrm{~cm})$ significantly better than BR $11(107.3 \mathrm{~cm})$, BRRIdhan $-33(103.7 \mathrm{~cm})$ as well as Sonarbangla-2 $(102.3 \mathrm{~cm})$.

Tillers/hill: Both the hybrids as well as BRRIdhan-32 produced a high range of effective tillers/hill (7.67-9.00) which were statistically similar. Sonarbangla-2 and BR11 did not vary significantly whereas BRRIdhan-33 possessed the lowest number. Regarding non-effect tillers/hill BRRIdhan32 showed an excellent record i.e. the minimum number per hill (1). While the figure was very high in case of the hybrid Sonarbangla-2 (5) and low with the rest $(2.00-2.67)$.

Panicle length: The longest panicle was formed by Sonarbangla-3 $(31.33 \mathrm{~cm})$ closely followed by Sonarbangla $-2(29.67 \mathrm{~cm})$. The former hybrid retained significant superiority to the conventional varieties $(24.67-28.33 \mathrm{~cm})$. However, Sonarbangla-2, BRRIdhan-32 and-33 were statistically similar. Variation among the treatments regarding no. of panicle/hill was not pronounced. Sonarbanla-3 obtained the highest filled up grains (176/panicle) but did not differ significantly with BRRIdhan-32 (149/panicle). Sonarbangla-3 had clear statistical edge over Sonarbangla-2, BRRIdhan-33 and BR11 in this respect.

100-grain weight: It is noted that the grains of the hybrids were clearly heavier, compared to those of the conventional varieties. The highest grain weight $(31 \mathrm{~g})$ was exhibited by Sonarbangla-2 followed by significantly different Sonarbangla-3 (28.33g). The conventional varieties had a medium range $(22-25 \mathrm{~g})$ of grain weight and were statistically lighter with respect to the hybrids.

Days to $1^{\text {st }}$ flowering and maturity: The hybrids became the earliest to flowering and maturity in comparison with the conventional varieties. Thus, Sonarbangla-2 and 3 took minimum days for flowering (92 and 95days) and maturity (108 and 115 days) followed distantly by the conventional varieties. The conventional varieties required maximum days (114-125 days) to flowering and 133150 days for maturity. It is observed that the hybrids were statistically superior to the conventional varieties regarding these parameters. 


\section{A. Awal et al.}

Yield of grain and straw: Sonarbangla-3 obtained the highest grain yield (6.20 t/ha), which significantly varied with the rest of the treatments. However, yield of BRRIdhan-32 (5.70 t/ha) was statistically higher than those of Sonarbangla-2 (5.15 t/ha) as well as other conventional varieties (4.17-4.96 t/ha). BRRIdhan-32 produced the top most straw yield (8.6 t/ha) which differed statistically with the rest of the treatment. Sonarbangla-3 produced a good amount of straw (6.5 t/ha) significantly higher than Sonarbangla-2 (5 t/ha), BR 11(5 t/ha) and BRRIdhan-33 (4.2 t/ha).

Harvest Index (\%): Harvest index was significantly influenced by different hybrid and varieties (Table1). The hybrid as well as the conventional varieties were statistically similar among themselves except BRRIdhan-32 which was significantly lower to the rest of the treatments.

\section{CONCLUSION}

The farmers of Sherpur district generally used T.aman-Fallow-Boro cropping pattern. For this reason the cropping intensity of this region was low. But instead of growing only the conventional rice varieties, if they would produce a hybrid one like Sonar Bangla-3, they might have some more benefits like confronting crisis usually appears during November-December in the study areas. These results indicated that after harvesting of short-duration hybrid rice Sonarbangla-3, farmers could cultivate different rabi crops like mustard/wheat/potato during the Fallow. Besides, they might have the opportunity for producing Boro as they did earlier. It may be concluded that the hybrid Sonarbangla-3 performed better than conventional varieties of rice. The hybrid may be recommended for cultivation during T.aman season.

\section{LITERATURE CITED}

Brammer. H.; Anlaime. J.; Kasem. A. H. and Velthuizem. H. T. 1988. Land Resource appraisal of Bangladesh for Agricultural, Development, Report-2. Agro-ecological Regions of Bangladesh. Food and Agriculture Organization (FAO). Rome. pp. 212-221.

Chandra, B. V., Mahadevappa, M., Krishnamurthy, A.H. and Bhasker, V.1992. Performance of IRRI rice hybrids in Mandya, Karnataka, India, Intl. Rice Res. Newsl. 17(2), 6.

Gromez. K. A. and Gomez. A. A. 1984. Statistical procedure for agricultural research. International Rice Research Institute. Hohn Willy and Sons, New York, Chicester, Brisbane, Toronto, Singapore.pp. 139-240.

Hossain, M .1996. 'Agricultural Policies in Bangladesh: Evaluation and Impact on Crop Production' in A Abdullah and A R Khan(eds), State, Market and Development: Essay in Honour of Rehman Sonhan, University Press, Dhaka, pp. 305-40

Julfiquar, A. W., M. M., Enamul Haque, A. K. G. M. and Rahsid, M. A. 1998. Current status of hybrid rice research and future programme in Bangladesh. A country report presented in the workshop on Use and Development of hybrid rice in Bangladesh held at BARC from May 18-19, 1998.

Quayum, M. A, Mustafi, B.A. A. and Baset, M. A. 1996.Ecinomics of Irrigated rice cultivation in selected areas of Bangladesh.Bangladesh, J. Agril. Research 21(1), 89-98.

Suprihatno, B and Sustaryo, B. 1992. Yield performance of some new rice hybrid in indonesia. Intl. Rice res. Newsl. 17(3), 12.

Siddiq, E. A. 1993. Rice production strategy for the $21^{\text {st }}$. Century. Oryza, 30, 186-196.

Varmani, S. S. 1994. Prospects of hybrid rice in the tropics and subtropics. In: hybrid Rice technology : New development and Future Prospects. (S.S Virmani, Ed.) Intl. Rice REs. Inst. Manila, Philippines. pp. 7-19.

Yuan, L. P. 1994. Increasing yield potential of rice by exploitation of heterosis. In: Hybrid Rice technology : New development and Future prospects (S. S. Virmani, ed.) Intl. Rice Res. Newsl., Manila, Philippines. pp. 1-6. 